Article

\title{
Simultaneous Extraction, Enrichment and Removal of Dyes from Aqueous Solutions Using a Magnetic Aqueous Micellar Two-Phase System
}

\author{
Shuanggen $\mathrm{Wu}^{1,+}$, Danyu Sun ${ }^{1,+}$, Chaoyun Wang ${ }^{2}$, Yuanru Yang ${ }^{2}$, Fenfang $\mathrm{Li}^{1}$ \\ and Zhijian Tan 2 * (iD \\ 1 College of Chemistry and Chemical Engineering, Central South University, Changsha 410083, China; \\ wushuanggen@csu.edu.cn (S.W.); danyusun@163.com (D.S.); lfflqq@csu.edu.cn (F.L.) \\ 2 Institute of Bast Fiber Crops and Center of Southern Economic Crops, Chinese Academy of Agricultural \\ Sciences, Changsha 410205, China; wangchaoyun@caas.cn (C.W.); yangyuanru@caas.cn (Y.Y.) \\ * Correspondence: tanzhijian@caas.cn; Tel.: +86-731-8899-8517 \\ + These authors contributed equally to this work.
}

Academic Editor: Bart Van der Bruggen

Received: 10 November 2017; Accepted: 29 November 2017; Published: 10 December 2017

\begin{abstract}
The magnetic aqueous micellar two-phase system (MAMTPS) has the advantages combined of magnetic solid phase extraction (MSPE) and aqueous micellar two-phase system (AMTPS). Thus, MAMTPS based on $\mathrm{Fe}_{3} \mathrm{O}_{4}$ magnetic nanoparticles (MNPs) and a nonionic surfactant Triton $\mathrm{X}-114$ (TX-114) was developed for the extraction, enrichment and removal of three dyes (Congo red, methyl blue, and methyl violet) from aqueous solutions in this study. The MNPs Fe $\mathrm{O}_{4} @ \mathrm{NH}_{2}$ was screened as the optimal MNPs benefiting the extraction. Then, the influencing factors of MNPs amount, TX-114 concentration, vibration time, and extraction temperature were investigated in detail. The results showed that the extraction efficiencies of three dyes almost reached $100 \%$ using MAMTPS under the optimal conditions; MAMTPS had higher extraction ability than the individual MSPE or AMTPS. Thus, MAMTPS had the advantages of simple operation, high extraction ability, easy recycling of MNPs, and short phase-separation time, which showspotential for use in the extraction and analysis of contaminants from water samples.
\end{abstract}

Keywords: magnetic nanoparticles; aqueous micellar two-phase system; nonionic surfactant; dyes; extraction

\section{Introduction}

Aqueous two-phase system (ATPS) is an effective and promising liquid-liquid extraction technology, which was first introduced by Albertson [1]. The main systems were PEG/dextran and PEG/salt in the early period, then more and more ATPSs appeared, such as the alcohol/salt system [2], aqueous micellar system [3], and ionic liquid/salt system [4]. The aqueous micellar two-phase system (AMTPS) based on non-ionic surfactant was a process of temperature-induced phase separation, which can form two phases above the cloud point temperature of non-ionic surfactant. Thus, AMTPS can be also called cloud point extraction (CPE). Compared with the other liquid-liquid extraction, the AMTPS has the advantages of low toxicity of surfactants, the use of dilute solutions, no use of organic solvents, high preconcentration factor due to the small volume in surfactant-rich phase, and good biocompatibility [5,6]. Likewise, the AMTPS has some disadvantages, such as the probable interference for analysis of target compounds caused by the co-existing hydrophobic species in the surfactant-rich phase, the high viscosity in surfactant-rich phase affecting the sample injection, and the long phase-separation time [7]. Up to now, the AMTPS was widely used in the extraction 
and separation field, such as the extraction of small molecule contaminants [8] or heavy metals [9] from aqueous solution, determination of pesticides in urine samples [10], determination of synthetic dyes [11] or heavy metals [12] in food samples, removal of dyes from wastewater [13], and extraction of bioactive compounds from natural plant resources [14].

Magnetic solid phase extraction (MSPE) using MNPs as the solid absorbent has aroused great interest in the field of analytical chemistry, which has the advantages of simple operation, high selectivity and enrichment factor for analytes, free of organic solvent, versatile use by easy surface modification of MNPs, moreover, the easy dispersion of MNPs to the solution and simple recovery of MNPs by using a permanent magnetic field [15-17]. Thus, MSPE was widely used in the extraction, separation and enrichment of various samples, including the biological, environmental and food samples [16].

This hybrid method of ATPS and magnetic separation was reported in other studies. For example, Dhadge and coworkers combined the PEG/dextran ATPS with magnetic separation for the purification of polyclonal human immunoglobulin $\mathrm{G}(\mathrm{IgG})$, satisfactory recovery yield and purity were obtained by this method, and the phase separation time was shorten from $40 \mathrm{~min}$ to $25 \mathrm{~min}$ compared with individual ATPS without addition of MNPs [18]. Fischer and coworkers developed a combined method of magnetic separation using functionalized MNPs and AMTPS using a non-ionic surfactant for the continuous purification of proteins [19]. In this study, a hybrid method of AMTPS and MSPE named magnetic aqueous micellar two-phase system (MAMTPS) was developed for the extraction, enrichment and removal of dyes from aqueous solutions. Up to now, the similar methods were mainly reported for the purification of biomolecules, such as the protein [20], chymotrypsin [21], and antibody [18], but no relevant study hasbeen reported about their use in the extraction/isolation of small molecules contaminants from aqueous solution. Therefore, three common dyes (Congo red, methyl blue, and methyl violet) were chosen as the target compounds in this study, the influencing factors of type and amount of MNPs, surfactant concentration, vibration time, and extraction temperature were studied to obtain the optimal operation conditions.

\section{Materials and Methods}

\subsection{Materials and Reagents}

The main materials used for the synthesis of MNPs were as follow: nano $\mathrm{Fe}_{3} \mathrm{O}_{4}(99.5 \%$ metals basis, $20 \mathrm{~nm}$ particle size), tetraethyl orthosilicate (TEOS), and (3-aminopropyl) triethoxysilane (APTES), which were purchased from Alladin Reagent Co., Ltd. (Shanghai, China). Triton X-114 $\left(\mathrm{C}_{30} \mathrm{H}_{64} \mathrm{O}_{9}\right.$, relative molar mass is $558.75 \mathrm{~g} / \mathrm{mol}, \mathrm{CMC}$ is $0.35 \mathrm{mmol} / \mathrm{L}$ at $25^{\circ} \mathrm{C}$ )was purchased from Alladin Reagent Co., Ltd. The dyes of Congo red (CR), methyl blue (MB), and methyl violet (MV) were purchased from Alladin Reagent Co., Ltd., and the chemical structures of the three dyes are shown in Figure 1. Other reagents were of analytical grade and used without further treatment. Deionized water was used to prepare the sample solutions.

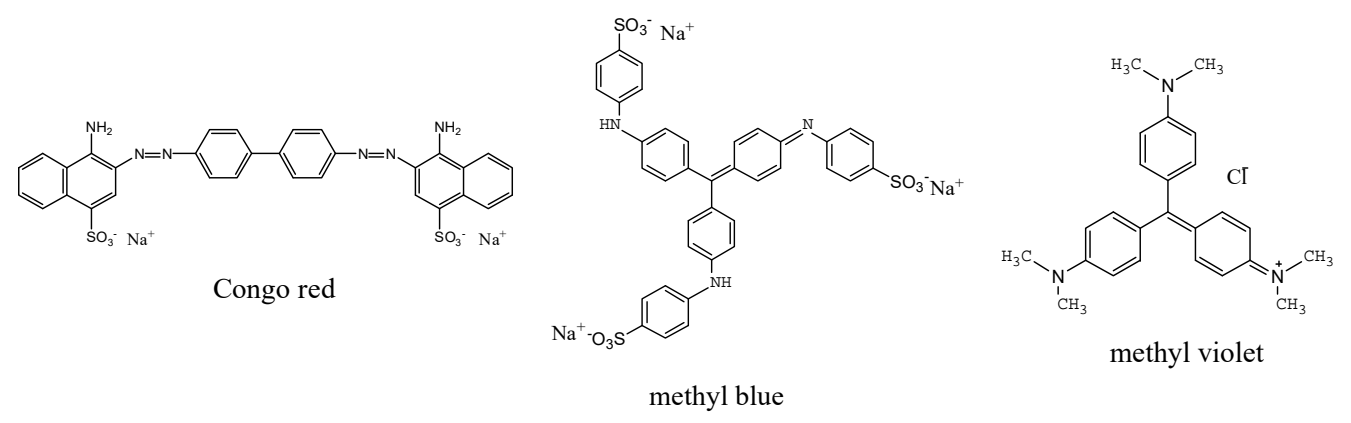

Figure 1. The chemical structures of the three dyes used in this study. 


\subsection{Preparation of Magnetic Nanoparticles}

\subsubsection{Preparation of $\mathrm{Fe}_{3} \mathrm{O}_{4} @ \mathrm{SiO}_{2}$}

The $\mathrm{Fe}_{3} \mathrm{O}_{4} @ \mathrm{SiO}_{2}$ was prepared according to the method previously reported with moderate modification [22]. To a three-necked flask, $3.0 \mathrm{~g} \mathrm{Fe}_{3} \mathrm{O}_{4}, 200 \mathrm{~mL}$ absolute ethanol, and $24 \mathrm{~mL}$ deionized water were added, and this mixture ultrasonically dispersed for $15 \mathrm{~min}$. Ten milliliters TEOS was added into the solution with continuous stirring. The $\mathrm{pH}$ value of the solution was adjusted to 9.0 by addition of $20 \mathrm{~mL} 10 \% \mathrm{NH}_{3} \cdot \mathrm{H}_{2} \mathrm{O}$. The solution was stirred for $12 \mathrm{~h}$ under the sealed condition. The $\mathrm{Fe}_{3} \mathrm{O}_{4} @ \mathrm{SiO}_{2}$ nanoparticles were magnetically separated and dried in vacuum drying oven (Shanghai Jing Hong Laboratory Instrument Co.,Ltd., Shanghai, China) at $60^{\circ} \mathrm{C}$ for $12 \mathrm{~h}$.

\subsubsection{Preparation of $\mathrm{Fe}_{3} \mathrm{O}_{4} @ \mathrm{NH}_{2}$ and $\mathrm{Fe}_{3} \mathrm{O}_{4} @ \mathrm{SiO}_{2}-\mathrm{NH}_{2}$}

The preparation of $\mathrm{Fe}_{3} \mathrm{O}_{4} @ \mathrm{NH}_{2}$ was referred to the method previously reported with moderate modification [22,23]. To a three-necked flask, $0.2 \mathrm{~g} \mathrm{Fe}_{3} \mathrm{O}_{4}, 1 \mathrm{~mL}$ water, $3 \mathrm{~mL} \mathrm{NH} \cdot \mathrm{H}_{2} \mathrm{O}$, and $150 \mathrm{~mL}$ absolute ethanol were added, and this mixture ultrasonically dispersed for $15 \mathrm{~min}$. Then $100 \mu \mathrm{L}$ APTES was added into the solution with continuous stirring. The reaction was conducted under nitrogen protection with continuous stirring for $24 \mathrm{~h}$ at room temperature. The $\mathrm{Fe}_{3} \mathrm{O}_{4} @ \mathrm{NH}_{2}$ nanoparticles were magnetically separated, then washed by absolute ethanol and dried in vacuum drying oven at $60^{\circ} \mathrm{C}$ for $12 \mathrm{~h}$. The procedures for preparation of $\mathrm{Fe}_{3} \mathrm{O}_{4} @ \mathrm{SiO}_{2}-\mathrm{NH}_{2}$ were similar to that of $\mathrm{Fe}_{3} \mathrm{O}_{4} @ \mathrm{NH}_{2}$ except the use of $\mathrm{Fe}_{3} \mathrm{O}_{4} @ \mathrm{SiO}_{2}$ instead of $\mathrm{Fe}_{3} \mathrm{O}_{4}$.

\subsection{Magnetic Solid-Phase Extraction}

To a tube, a certain amount of MNPs and dyes aqueous solution was added. Then the tube was placed in a shaking bath (model SHZ-B, Shanghai Boxun Medical Biological Instrument Corp., Shanghai, China) for a certain time at constant temperature. A permanent magnet $(40 \times 20 \mathrm{~mm})$, (Dongguan XiangXiong Magnet Co., Ltd., Dongguan, China) was used to attract the MNPs to the bottom of the tube. Then the aqueous solution was carefully withdrawn for analysis of the content of dyes.

\subsection{Aqueous Micellar Two-Phase Extraction}

To a tube, a certain amount of TX-114 and dyes aqueous solution was added. The tube was well agitated using an agitator (model MX-S, Dragon Laboratory Instruments Limited, Beijing, China) to make the TX-114 dissolve completely. Then the tube was placed in the water bath (model HWCL-5, Zhengzhou Greatwall Scientific Industrial and Trade Co, Ltd., Zhengzhou, China) for a certain time at constant temperature. The phase separation was achieved above the cloud point and the dyes were extracted into the bottom phase (surfactant rich phase). The content of dyes in the top phase (aqueous phase) was analyzed, and the content of dyes in the bottom phase was calculated by the subtraction method.

\subsection{Magnetic Aqueous Micellar Two-Phase Extraction}

To a tube, a certain amount of TX-114, MNPs, and dyes aqueous solution was added. The tube was well agitated to make the TX-114 dissolve completely and the MNPs well disperse in the surfactant solution. Then the tube was placed in a shaking bath for a certain time at constant temperature. The tube was stood for $10 \mathrm{~min}$ in the bath without shaking for phase separation. The volume of each phase was noted down. The content of dyes in the top phase (aqueous phase) was analyzed, and the mass of dyes in the bottom phase was obtained by the subtraction method from the total mass of dyes added to the tube. 


\subsection{Quantitative Determination of Dyes}

The quantitative determination of dyes concentration was operated by using an UV-Vis spectrophotometer (model UV-3000, Shanghai MAPADA Instruments Co., Ltd., Shanghai, China). The samples in the top phase (aqueous phase) of MAMTPS were withdrawn and diluted for analysis of the content of dyes. Another tube with the same components but without dyes was used as the blank. The dyes were extracted and adsorbed in the bottom phase (surfactant rich phase). The absorbance of each dye was determined, and then the mass of dyes in the top phase was calculated. The mass of dyes in the bottom phase was obtained by the subtraction method from the total mass of dyes added to the tube. The extraction efficiency of dyes in the bottom phase was defined in the Equation (1):

$$
\text { Extraction efficiency }(\%)=\frac{M_{b}}{M_{0}}=\frac{M_{0}-C_{t} V_{t}}{M_{0}} \times 100
$$

where $M_{b}$ and $M_{0}$ represented the mass of dyes in the top phase and the original mass added to the tube, respectively. $C_{t}$ and $V_{t}$ represented the concentration of dyes and volume of top phase, respectively. The detection conditions and standard curves for analysis of the three dyes are shown in Table 1 . The standard curves were constructed by plotting the absorbance $(Y)$ as a function of the pure dyes concentration $(X)$.

Table 1. The detection conditions and standard curves for analysis of dyes.

\begin{tabular}{ccccc}
\hline Samples & Standard Curves & $\begin{array}{c}\text { Detection } \\
\text { Wavelength } \mathbf{( n m )}\end{array}$ & $\begin{array}{c}\text { Linear Range } \\
\mathbf{( m g / m L )}\end{array}$ & $\begin{array}{c}\text { Correlation } \\
\text { Coefficient }\left(\mathbf{R}^{\mathbf{2}}\right)\end{array}$ \\
\hline Congo red & $Y=13.459 X+0.0398^{\text {a }}$ & 498 & $0.01-0.16$ & 0.9994 \\
Methyl blue & $Y=24.708 X-0.0282^{\text {a }}$ & 577 & $0.01-0.16$ & 0.9993 \\
Methyl violet & $Y=35.356 X-0.0261^{\text {a }}$ & 570 & $0.005-0.08$ & 1.0000 \\
\hline \multicolumn{5}{c}{${ }^{a} Y$ was the absorbance and $X$ was the dyes concentration. }
\end{tabular}

\subsection{Statistical Analysis}

The SAS software (version 9.4, SAS Institute Inc., Cary, NC, USA) was performed for the statistical analysis. The statistical analysis for optimization of the extraction conditions was done using the Duncan's multiple range test. The $p$ values $<0.05$ were considered statistically significant. Each error bar indicates the standard deviation of triplicate tests. Different letters on histograms indicate that means are statistically different at the $p<0.05$ level.

\section{Results and Discussion}

\subsection{Characterization of the Magnetic Nanoparticles by Fourier-Transform Infrared Spectroscopy}

The MNPs samples were characterized by Fourier-Transform Infrared Spectroscopy (FT-IR), the results were shown in Figure 2. It can be seen that all the MNPs have the absorbance peaks around $3400 \mathrm{~cm}^{-1}$ and $1630 \mathrm{~cm}^{-1}$, which was contributed by the hydroxyl of water in the MNPs. All the MNPs have a stretching vibration peak around $580 \mathrm{~nm}$ for $\mathrm{Fe}-\mathrm{O}$ bond. $\mathrm{Fe}_{3} \mathrm{O}_{4} @ \mathrm{NH}_{2}$ and $\mathrm{Fe}_{3} \mathrm{O}_{4} @ \mathrm{SiO}_{2}-\mathrm{NH}_{2}$ have stretching vibration peaks around 1092 for $\mathrm{Si}-\mathrm{O}$ bond. Due to the amidogen in $\mathrm{Fe}_{3} \mathrm{O}_{4} @ \mathrm{NH}_{2}$ and $\mathrm{Fe}_{3} \mathrm{O}_{4} @ \mathrm{SiO}_{2}$ was interfered by the hydroxyl of water, it is hard to identify the amidogen in the MNPs. Thus, a further step for the quantitative determination of amidogen was performed by ninhydrin test [24]. The results showed that the amidogenin $\mathrm{Fe}_{3} \mathrm{O}_{4} @ \mathrm{NH}_{2}$ and $\mathrm{Fe}_{3} \mathrm{O}_{4} @ \mathrm{SiO}_{2}-\mathrm{NH}_{2}$ was 0.64 and $0.512 \mathrm{mg} / \mathrm{g}$, respectively. 


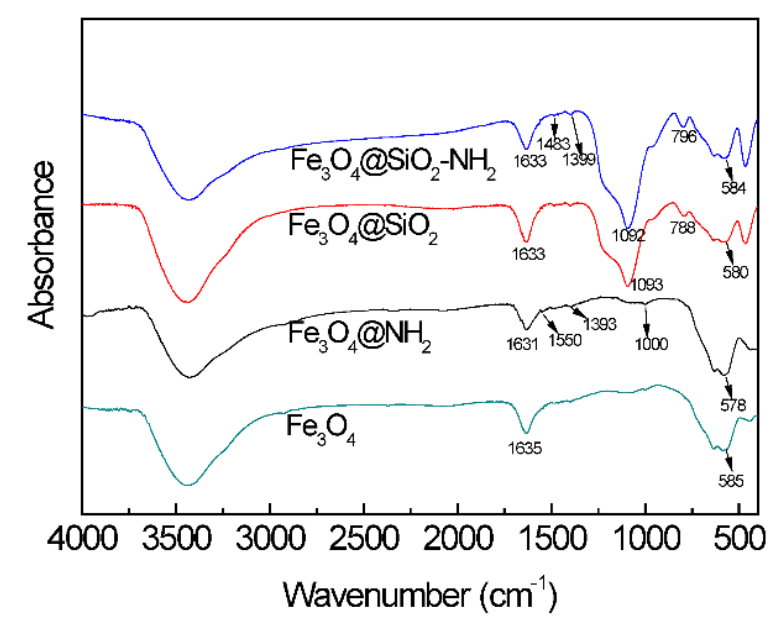

Figure 2. The Fourier-Transform Infrared Spectroscopy (FT-IR) for the magnetic nanoparticles (MNPs).

\subsection{Selection of the Optimal Magnetic Nanoparticles}

The addition of MNPs to the aqueous micellar two-phase system can improve the extraction and shorten the phase-forming time. Thus, four kinds of MNPs, $\mathrm{Fe}_{3} \mathrm{O}_{4}, \mathrm{Fe}_{3} \mathrm{O}_{4} @ \mathrm{NH}_{2}, \mathrm{Fe}_{3} \mathrm{O}_{4} @ \mathrm{SiO}_{2}$, and $\mathrm{Fe}_{3} \mathrm{O}_{4} @ \mathrm{SiO}_{2}-\mathrm{NH}_{2}$, were considered. It can be seen in Figure 3 that the MNPs can increase the extraction efficiency of dyes, the order of the extraction efficiency by addition of MNPs was as follow: $\mathrm{Fe}_{3} \mathrm{O}_{4} @ \mathrm{NH}_{2}>\mathrm{Fe}_{3} \mathrm{O}_{4} @ \mathrm{SiO}_{2}-\mathrm{NH}_{2}>\mathrm{Fe}_{3} \mathrm{O}_{4} @ \mathrm{SiO}_{2}>\mathrm{Fe}_{3} \mathrm{O}_{4}$. The reason for interpreting this was the stronger hydrogen-bond interaction thatcould be occurring between $-\mathrm{NH}_{2}$ and the dyes. The reason for $\mathrm{MNPs} \mathrm{Fe}_{3} \mathrm{O}_{4} @ \mathrm{SiO}_{2}-\mathrm{NH}_{2}$ was inefficient than $\mathrm{Fe}_{3} \mathrm{O}_{4} @ \mathrm{NH}_{2}$ was that less $-\mathrm{NH}_{2}$ in the surface of $\mathrm{Fe}_{3} \mathrm{O}_{4} @ \mathrm{SiO}_{2}-\mathrm{NH}_{2}$ after being coated by silica. Moreover, the extraction efficiency of the three dyes follow the order $\mathrm{CR}>\mathrm{MV}>\mathrm{MB}$ using $\mathrm{Fe}_{3} \mathrm{O}_{4} @ \mathrm{NH}_{2}$ in system. The reason for interpreting this is that hydrogen-bond interaction can be occurring between- $\mathrm{NH}_{2}$ in $\mathrm{Fe}_{3} \mathrm{O}_{4} @ \mathrm{NH}_{2}$ and $-\mathrm{NH}_{2}$ in CR, moreover $-\mathrm{NH}_{2}$ in $\mathrm{Fe}_{3} \mathrm{O}_{4} @ \mathrm{NH}_{2}$ and $\mathrm{Cl}^{-}$in $\mathrm{MV}$ (seeing the structures of dyes in Figure 1). Therefore, the MNPs $\mathrm{Fe}_{3} \mathrm{O}_{4} @ \mathrm{NH}_{2}$ was chosen for further studies.

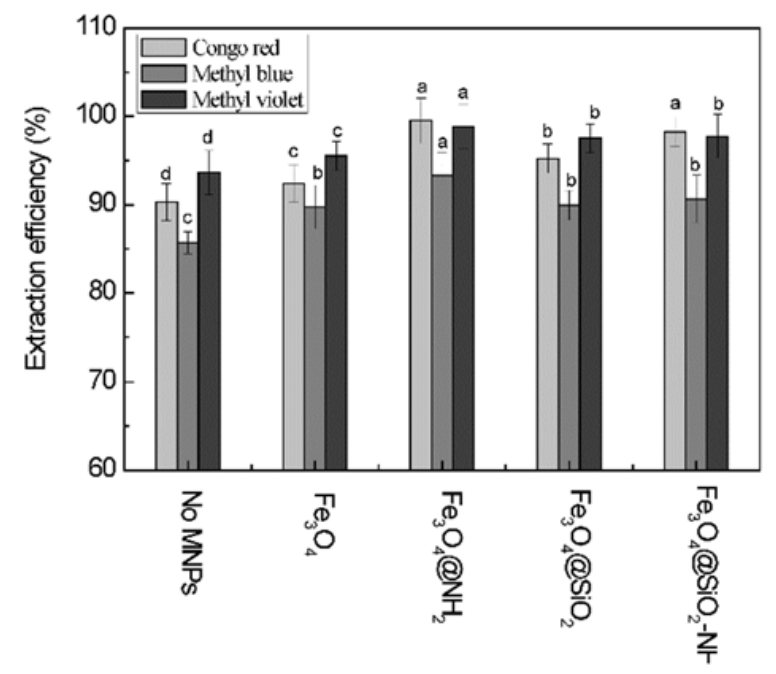

Figure 3. Effect of the MNPs added to the aqueous micellar two-phase system (AMTPS) on the extraction efficiency of dyes. (Each system contained $10 \mathrm{~mL}$ dyes solution $(1 \mathrm{mg} / \mathrm{mL}$ Congo red (CR), methyl blue (MB) and $0.125 \mathrm{mg} / \mathrm{mL}$ methyl violet (MV)). $10 \mathrm{mg}$ MNPs, $4 \mathrm{wt}$. \% TX-114, 40 min vibration time, and incubated at temperature $40{ }^{\circ} \mathrm{C}$ for $10 \mathrm{~min}$ ). Different letters in the same series indicate significant difference at $p<0.05$ level. 


\subsection{Effect of the Magnetic Nanoparticles Amount}

The effect of the MNPs amount was investigated with 2-10 mg Fe $\mathrm{O}_{4} @ \mathrm{NH}_{2}$ being added into the AMTPS, no addition of MNPs was used as the control. It can be found in Figure 4 that the extraction efficiencies had minor increase with further increase of MNPs when the MNPs amount was larger than $4 \mathrm{mg}$. The results demonstrated that the extraction mainly depend on the TX-114, however, the MNPs can also increase the extraction efficiency to some extent and accelerate the phase forming. Thus, to comprehensively consider the extraction efficiency and the phase forming, $4 \mathrm{mg}$ MNPs were added to the system for further studies.

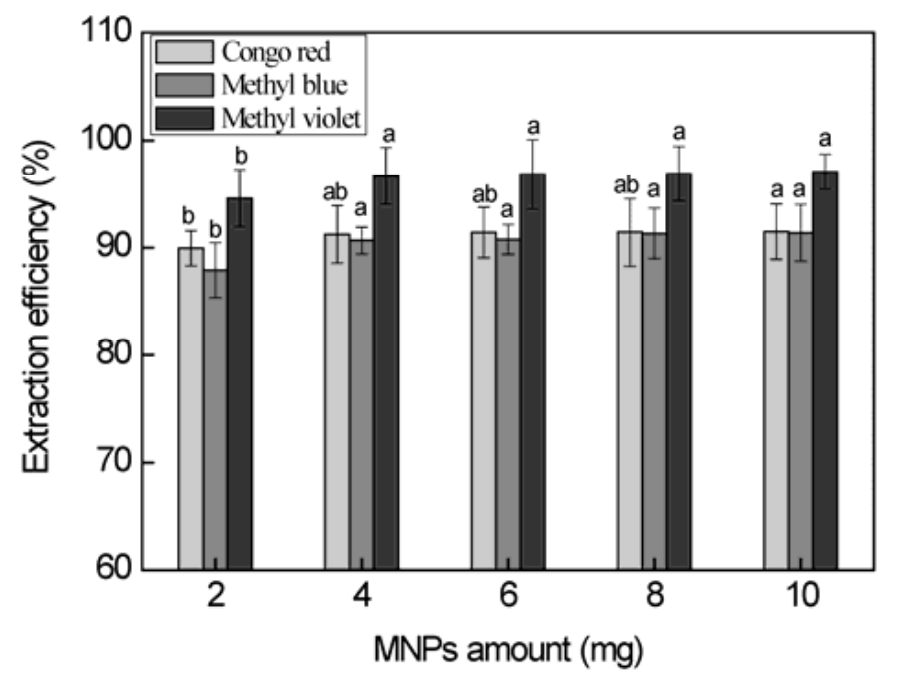

Figure 4. Effect of the $\mathrm{Fe}_{3} \mathrm{O}_{4} @ \mathrm{NH}_{2}$ amount added to the AMTPS on the extraction efficiency of dyes. (Each system contained $10 \mathrm{~mL}$ dyes solution $(1 \mathrm{mg} / \mathrm{mL} \mathrm{CR,} \mathrm{MB} \mathrm{and} 0.125 \mathrm{mg} / \mathrm{mL} \mathrm{MV}), 4$ wt. \% TX-114, $40 \mathrm{~min}$ vibration time, and incubated at temperature $40{ }^{\circ} \mathrm{C}$ for $10 \mathrm{~min}$ ). Different letters in the same series indicate significant difference at $p<0.05$ level.

\subsection{Effect of the TX-114 Concentration}

TX-114 was chosen in this study due to its ambient cloud point $\left(23-25{ }^{\circ} \mathrm{C}\right)$ at different concentrations, low toxicological properties and cost, in addition the high density in surfactant rich phase facilitating phase separation by centrifugation, which was the most popular nonionic surfactant used in the CPE [25-27]. The effect of TX-114 concentration can be the major factor influencing the extraction. The TX-114 solution can form two phase above the cloud point temperature, a lower phase with high surfactantconcentration, and the other aqueous top phase with low surfactant concentration (slightly above the CMC of TX-114) [28]. Thus, the effect of TX-114 concentration in the range of 1-5 wt. \% (weight ratio) was investigated. The phase-separation cannot be achieved at $1 \mathrm{wt}$. \% TX-114 concentration during the extraction of CR and MV. It can be seen in Figure 5 that the extraction efficiencies obviously increased with increase of TX-114 concentration. Because the extraction mainly depended on the TX-114 and the influence of MNPs to extraction efficiency can be concealed at high TX-114 concentration, thus, the 4 wt. \% TX-114 concentration was chosen for further studies. 


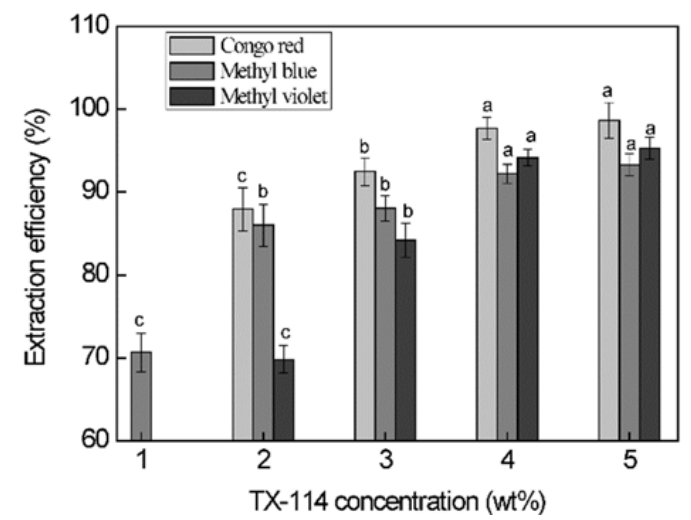

Figure 5. Effect of the Triton X-114 (TX-114) concentration on the extraction efficiency of the dyes. (Each system contained $10 \mathrm{~mL}$ dyes solution $(1 \mathrm{mg} / \mathrm{mL} \mathrm{CR}, \mathrm{MB}$ and $0.125 \mathrm{mg} / \mathrm{mL} \mathrm{MV}), 4 \mathrm{mg}$ $\mathrm{Fe}_{3} \mathrm{O}_{4} @ \mathrm{NH}_{2}, 40 \mathrm{~min}$ vibration time, and incubated at temperature $40{ }^{\circ} \mathrm{C}$ for $10 \mathrm{~min}$ ). Different letters in the same series indicate significant difference at $p<0.05$ level.

\subsection{Effect of the Vibration Time}

The extraction was performed in a shaking bath, the vibration time of 20-320 min was studied, and no vibration was used as the control. The role of the vibration is to make sufficient contact for the dyes with the surfactant and MNPs. The results in Figure 6 showed that the extraction of the threedyes was significantly affected by the vibration compared with the controls, but the extraction efficiencies varied little with the vibration time larger than $20 \mathrm{~min}$. Thus, the vibration time of $20 \mathrm{~min}$ was enough for the extraction.

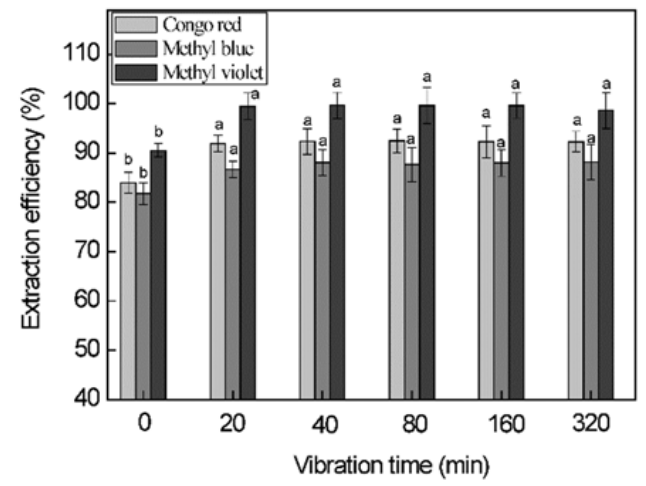

Figure 6. Effect of the vibration time on the extraction efficiency of the dyes. (Each system contained $10 \mathrm{~mL}$ dyes solution ( $1 \mathrm{mg} / \mathrm{mL} \mathrm{CR}, \mathrm{MB}$ and $0.125 \mathrm{mg} / \mathrm{mL} \mathrm{MV}), 4 \mathrm{mg} \mathrm{Fe} \mathrm{O}_{4} @ \mathrm{NH}_{2}, 4$ wt. \% TX-114, and incubated at temperature $40^{\circ} \mathrm{C}$ for $10 \mathrm{~min}$ ). Different letters in the same series indicate significant difference at $p<0.05$ level.

\subsection{Effect of Extraction Temperature}

The TX-114 is a thermo-sensitive polymer, thus, the extraction can be affected by the temperature. It was found that the addition of dyes can raise the cloud point of TX-114, so in order to make sure the phase-separation can be achieved, the effect of temperature in the range of $30-50{ }^{\circ} \mathrm{C}$ for $\mathrm{CR}$ and $\mathrm{MV}$ and $40-60{ }^{\circ} \mathrm{C}$ for $\mathrm{MB}$ was studied, respectively. The results in Figure 7 showed that the extraction efficiency for $\mathrm{CR}$ had minor increase with increase of temperature from 30 to $40{ }^{\circ} \mathrm{C}$, then varied little with further increase of temperature; the extraction efficiency for $\mathrm{MB}$ increased with increase of temperature from 40 to $45^{\circ} \mathrm{C}$, then also varied little with increase of temperature; the extraction efficiency for $\mathrm{MV}$ varied little at the temperature range of $30-50{ }^{\circ} \mathrm{C}$. All these results indicated that the extraction efficiency reached the maximum above a certain temperature then didn't increase with 
further increase of temperature in this study, the similar results were observed in other CPE using non-surfactant as extractant $[29,30]$. Thus, the optimal extraction temperature was different for each dye, and the heating wasbeneficial for the extraction.

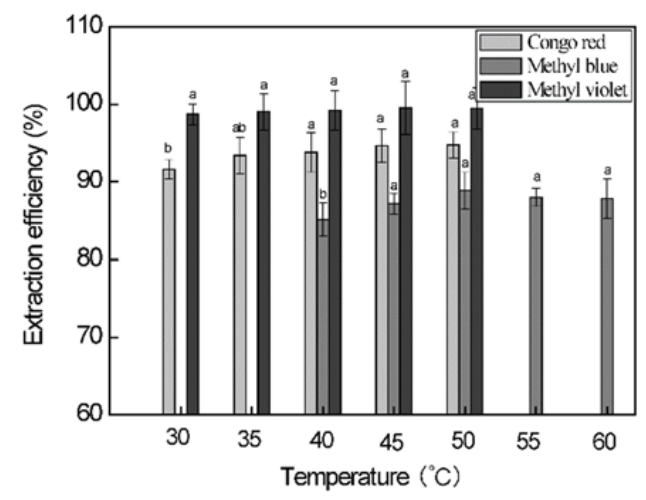

Figure 7. Effect of the temperature on the extraction efficiency of the dyes. (Each system contained

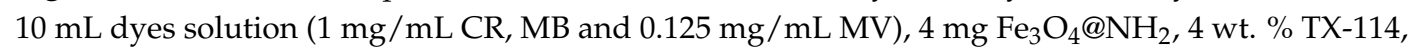
$20 \mathrm{~min}$ vibration time, and incubated at different temperatures for $10 \mathrm{~min}$ ). Different letters in the same series indicate significant difference at $p<0.05$ level.

\subsection{Comparison of Magnetic Aqueous Micellar Two-Phase System to Magnetic Solid Phase Extraction and} Aqueous Micellar Two-Phase System

The MAMTPS was combined with the MSPE and AMTPS, thus, it has the advantages of both MSPE and AMTPS. The results of extraction efficiencies for MAMTPS, MSPE and AMTPS, and the phase-separation time for MAMTPS and AMTPS were shown in Figure 8. It can be seen that theMAMTPS had higher extraction efficiency than MSPE and AMTPS. Moreover, MAMTPS had short extraction time than MSPE, the extraction time was $20 \mathrm{~min}$ and phase equilibrium time was about $10 \mathrm{~min}$ for MAMTPS, which was much shorter than that of $4 \mathrm{~h}$ vibration timeforMSPE. The complete phase-separation time of MAMTPS was reduced by $>37 \%$ compared with AMTPS at different TX-114 concentration. Similar results were reported that the addition of MNPs can shorten the phase separation time in other ATPSs $[18,31]$.

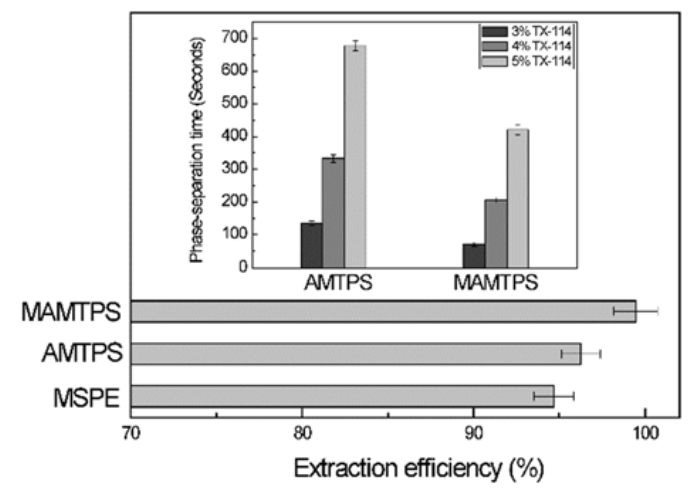

Figure 8. Comparison of the extraction efficiency of CR and phase-separation time of magnetic aqueous micellar two-phase system (MAMTPS) to magnetic solid phase extraction (MSPE) and aqueous micellar

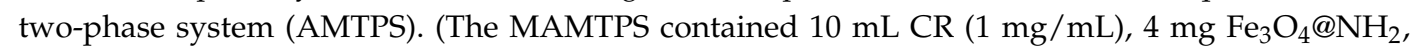
4 wt. \% TX-114, $40 \mathrm{~min}$ vibration time, and incubated at temperature $40^{\circ} \mathrm{C}$ for $10 \mathrm{~min}$; the AMTPS contained $10 \mathrm{~mL} \mathrm{CR}(1 \mathrm{mg} / \mathrm{mL}), 4 \mathrm{wt}$. \% TX-114, $40 \mathrm{~min}$ vibration time, and incubated at temperature $40{ }^{\circ} \mathrm{C}$ for $10 \mathrm{~min}$, the MSPE contained $10 \mathrm{~mL} \mathrm{CR}(1 \mathrm{mg} / \mathrm{mL}), 10 \mathrm{mg} \mathrm{Fe} \mathrm{O}_{4} @ \mathrm{NH}_{2}, 4 \mathrm{~h}$ vibration time). The phase-separation time was determined at $3-5 \mathrm{wt} . \% \mathrm{TX}-114$ and $30^{\circ} \mathrm{C}$ water bath. 


\section{Conclusions}

In this study, a novel method of MAMTPS was employed for the extraction, enrichment and removal of dyes from aqueous solutions in one-step extraction. This MAMTPSis more efficient than the individual AMTPS or MSPE, which were widely used for the extraction of dyes from various solution samples. The $\mathrm{Fe}_{3} \mathrm{O}_{4} @ \mathrm{NH}_{2}$ was chosen as the optimal MNPs added to the extraction systemunder the following conditions: each system contained $10 \mathrm{~mL}$ dyes solution $(1 \mathrm{mg} / \mathrm{mL} \mathrm{CR}$ and $\mathrm{CB}$ and $0.125 \mathrm{mg} / \mathrm{mL} \mathrm{MV}), 4 \mathrm{mg}$ MNPs, 4 wt. \% TX-114, $20 \mathrm{~min}$ vibration time, and suitable temperature, the extraction efficiency of the three dyes almost reached $100 \%$. This MAMTPS was much simpler, free of organic solvents, and easy recycling of MNPs.Moreover, it has high extraction ability and short phase separation time (reduced by $>37 \%$ at different TX-114 concentration), making it ofpotential use in the extraction, analysis and removal of contaminants from environmental samples.

Acknowledgments: This work was financially supported by the National Natural Science Foundation of China (No. 21406262), the Agricultural Science and Technology Innovation Program (No. ASTIP-IBFC07), Central Public-interest Scientific Institution Basal Research Fund (No. 1610242016006), and the Fundamental Research Funds for the Central Universities of Central South University (No. 2017zzts336).

Author Contributions: Zhijian Tan, Chaoyun Wang and Fenfang Li conceived and designed the experiments; Shuanggen $\mathrm{Wu}$ and Danyu Sun performed the experiments; Zhijian Tan and Yuanru Yang analyzed the data; Zhijian Tan wrote and revised the paper.

Conflicts of Interest: The authors declare no conflict of interest.

\section{References}

1. Albertsson, P.A. Partition of Cell Particles and Macromolecules; Wiley: New York, NY, USA, 1986.

2. Tan, T.W.; Huo, Q.; Ling, Q. Purification of glycyrrhizin from Glycyrrhiza uralensis Fisch with ethanol/ phosphate aqueous two-phase system. Biotechnol. Lett. 2002, 24, 1417-1420.

3. Nikas, Y.; Liu, C.; Srivastava, T.; Abbott, N.; Blankschtein, D. Protein partitioning in two-phase aqueous nonionic micellar solutions. Macromolecules 1992, 25, 4797-4806. [CrossRef]

4. Gutowski, K.E.; Broker, G.A.; Willauer, H.D.; Huddleston, J.G.; Swatloski, R.P.; Holbrey, J.D.; Rogers, R.D. Controlling the aqueous miscibility of ionic liquids: Aqueous biphasic systems of water-miscible ionic liquids and water-structuring salts for recycle, metathesis, and separations. J. Am. Chem. Soc. 2003, 125, 6632-6633. [CrossRef] [PubMed]

5. Altunay, N.; Gurkan, R. A new cloud point extraction procedure for determination of inorganic antimony species in beverages and biological samples by flame atomic absorption spectrometry. Food Chem. 2015, 175, 507-515. [CrossRef] [PubMed]

6. Zhou, J.; Sun, J.B.; Xu, X.Y.; Cheng, Z.H.; Zeng, P.; Wang, F.Q.; Zhang, Q. Application of mixed cloud point extraction for the analysis of six flavonoids in Apocynum venetum leaf samples by high performance liquid chromatography. J. Pharm.Biomed. 2015, 107, 273-279. [CrossRef] [PubMed]

7. Wang, Y.; Chen, H.; Han, J.; Wang, L.; Ni, L.; Wang, T.; Tang, X. A novel cyclic non-ligand dualcloud point extraction for the preconcentration of Cadmium(II) through $\mathrm{pH}$ regulation in food and environmental matrices. New J. Chem. 2015, 39, 9116-9123. [CrossRef]

8. Norseyrihan, M.; Noorashikin, M.; Adibah, M.; Yusoff, F. Cloud point extraction of methylphenol in water samples with low viscosity of non-ionic surfactant Sylgard 309 coupled with high-performance liquid chromatography. Sep. Sci. Technol. 2016, 51, 2386-2393. [CrossRef]

9. Youcef, M.H.; Benabdallah, T.; Reffas, H. Cloud point extraction studies on recovery of Nickel (II) from highly saline sulfate medium using salicylideneaniline mono-schiff base chelating extractant. Sep. Purif. Technol. 2015, 149, 146-155. [CrossRef]

10. Madej, K.; Sekiewicz, A.; Kalenik, T.K.; Piekoszewski, W. Cloud-point extraction followed by high pressure liquid chromatography with UV spectrophotometric detection for determination of permethrin in urine samples. Anal. Methods UK 2015, 7, 7758-7764. [CrossRef] 
11. Heidarizadi, E.; Tabaraki, R. Simultaneous spectrophotometric determination of synthetic dyes in food samples after cloud point extraction using multiple response optimizations. Talanta 2016, 148, $237-246$. [CrossRef] [PubMed]

12. Wang, Y.; Han, J.; Liu, Y.; Wang, L.; Ni, L.; Tang, X. Recyclable non-ligand dual cloud point extraction method for determination of lead in food samples. Food Chem. 2016, 190, 1130-1136. [CrossRef] [PubMed]

13. Melo, R.P.F.; Barros Neto, E.L.; Moura, M.C.P.A.; Castro Dantas, T.N.; Dantas Neto, A.A.; Oliveira, H.N.M. Removal of reactive Blue 19 using nonionic surfactant in cloud point extraction. Sep. Purif. Technol. 2014, 138, 71-76. [CrossRef]

14. Tan, Z.J.; Li, F.F.; Xing, J.M. Cloud point extraction of aloe anthraquinones based on non-ionic surfactant aqueous two-phase system. Nat. Prod. Res. 2012, 26, 1423-1432. [CrossRef] [PubMed]

15. Cheng, G.; He, M.; Peng, H.; Hu, B. Dithizone modified magnetic nanoparticles for fast and selective solid phase extraction of trace elements in environmental and biological samples prior to their determination by ICP-OES. Talanta 2012, 88, 507-515. [CrossRef] [PubMed]

16. Wierucka, M.; Biziuk, M. Application of magnetic nanoparticles for magnetic solid-phase extraction in preparing biological, environmental and food samples. TrAC-Trend Anal. Chem. 2014, 59, 50-58. [CrossRef]

17. Gao, Q.; Luo, D.; Bai, M.; Chen, Z.-W.; Feng, Y.-Q. Rapid determination of estrogens in milk samples based on magnetite nanoparticles/polypyrrole magnetic solid-phase extraction coupled with liquid chromatography-tandem mass spectrometry. J. Agric. Food Chem. 2011, 59, 8543-8549. [CrossRef] [PubMed]

18. Dhadge, V.L.; Rosa, S.A.S.L.; Azevedo, A.; Aires-Barros, R.; Roque, A.C.A. Magnetic aqueous two phase fishing: A hybrid process technology for antibody purification. J. Chromatogr. A 2014, 1339, 59-64. [CrossRef] [PubMed]

19. Fischer, I.; Hsu, C.-C.; Gartner, M.; Muller, C.; Overton, T.W.; Thomas, O.R.; Franzreb, M. Continuous protein purification using functionalized magnetic nanoparticles in aqueous micellar two-phase systems. J. Chromatogr. A. 2013, 1305, 7-16. [CrossRef] [PubMed]

20. Gai, Q.; Qu, F.; Zhang, T.; Zhang, Y. Integration of carboxyl modified magnetic particles and aqueous two-phase extraction for selective separation of proteins. Talanta 2011, 85, 304-309. [CrossRef] [PubMed]

21. Paulus, A.; Morhardt, C.; Lehle, N.; Franzreb, M. Recovery of chymotrypsin using magnetic particles and aqueous micellar two-phase systems: Influence of non-ionic surfactants on enzyme activity. J. Mol. Catal. B. Enzym. 2014, 110, 165-170. [CrossRef]

22. Zhang, J.M.; Zhai, S.-R.; Zhai, B.; An, Q.D.; Tian, G. Crucial factors affecting the physicochemical properties of sol-gel produced $\mathrm{Fe}_{3} \mathrm{O}_{4} @ \mathrm{SiO}_{2}-\mathrm{NH}_{2}$ core-shell nanomaterials. J. Sol-Gel Sci. Technol. 2012, 64, 347-357. [CrossRef]

23. Xie, G.; Xi, P.; Liu, H.; Chen, F.; Huang, L.; Shi, Y.; Hou, F.; Zeng, Z.; Shao, C.; Wang, J. A facile chemical method to produce superparamagnetic graphene oxide- $\mathrm{Fe}_{3} \mathrm{O}_{4}$ hybrid composite and its application in the removal of dyes from aqueous solution. J. Mater. Chem. 2012, 22, 1033-1039. [CrossRef]

24. Zhang, S.; Du, B.; Li, H.; Xin, X.; Ma, H.; Wu, D.; Yan, L.; Wei, Q. Metal ions-based immunosensor for simultaneous determination of estradiol and diethylstilbestrol. Biosens. Bioelectron. 2014, 52, 225-231. [CrossRef] [PubMed]

25. Han, Q.; Huo, Y.; Yang, N.; Yang, X.; Hao, T. Determination of cobalt in water by thermal lens spectrometry with cloud point extraction. Anal. Lett. 2015, 48, 2096-2106. [CrossRef]

26. Altunay, N.; Gurkan, R. Determination of low levels of Cd (II) in cosmetic products by spectrophotometry after separation/preconcentration with cloud point extraction. Anal. Methods UK 2016, 8, 2673-2683. [CrossRef]

27. Peng, G.; He, Q.; Zhou, G.; Li, Y.; Su, X.; Liu, M.; Fan, L. Determination of heavy metals in water samples using dual-cloud point extraction coupled with inductively coupled plasma mass spectrometry. Anal. Methods UK 2015, 7, 6732-6739. [CrossRef]

28. Ghaedi, M.; Shokrollahi, A.; Ahmadi, F.; Rajabi, H.R.; Soylak, M. Cloud point extraction for the determination of copper, nickel and cobalt ions in environmental samples by flame atomic absorption spectrometry. J. Hazard. Mater. 2008, 150, 533-540. [CrossRef] [PubMed] 
29. Niazi, A.; Ghasemi, J.; Yazdanipour, A. Simultaneous spectrophotometric determination of nitroaniline isomers after cloud point extraction by using least-squares support vector machines. Spectrochim. Acta A. 2007, 68, 523-530. [CrossRef] [PubMed]

30. Zhu, X.S.; Hu, B.; Jiang, Z.C.; Li, M.F. Cloud point extraction for speciation of chromium in water samples by electrothermal atomic absorption spectrometry. Water Res. 2005, 39, 589-595. [CrossRef] [PubMed]

31. Wikstrom, P.; Flygare, S.; Grondalen, A.; Larsson, P.-O. Magnetic aqueous two-phase separation: A new technique to increase rate of phase-separation, using dextran-ferrofluid or larger iron oxide particles. Anal. Biochem. 1987, 167, 331-339. [CrossRef]

(C) 2017 by the authors. Licensee MDPI, Basel, Switzerland. This article is an open access article distributed under the terms and conditions of the Creative Commons Attribution (CC BY) license (http://creativecommons.org/licenses/by/4.0/). 